Notre Dame Law School

NDLScholarship

Journal Articles

Publications

2016

\title{
Subsidiarity's Roots and History: Some Observations
}

John M. Finnis

Notre Dame Law School, john.m.finnis.1@nd.edu

Follow this and additional works at: https://scholarship.law.nd.edu/law_faculty_scholarship Part of the Natural Law Commons

\section{Recommended Citation}

John M. Finnis, Subsidiarity's Roots and History: Some Observations, 61 Am. J. Juris. 133 (2016).

Available at: https://scholarship.law.nd.edu/law_faculty_scholarship/1256

This Article is brought to you for free and open access by the Publications at NDLScholarship. It has been accepted for inclusion in Journal Articles by an authorized administrator of NDLScholarship. For more information, please contact lawdr@nd.edu. 


\title{
Subsidiarity's Roots and History: Some Observations
}

\author{
John Finnis*
}

\begin{abstract}
Subsidiarity, i.e., "the principle of subsidiarity," i.e., "the principle of subsidiary function/responsibility," i.e., the principle that it is unjust for a higher authority (e.g., the state's government and law) to usurp the self-governing authority that lower authorities (e.g., in families or other civil associations), acting in the service of their own members (groups and persons), rightly have over those members, is a presumptive and defeasible, not an absolute, principle. But it excludes any general policy or aim of assuming the control or managerial direction of lower groups. Its deepest rationale is the intrinsic desirability of self-direction (not least in cooperatively associating with other persons), a good that is to be favored and respected even at the expense of some efficiency in the pursuit of other goods. Though arising out of Aristotelean moral and political theory, it denies or strongly disambiguates a cardinal principle of Aristotelean political theory. It is reflected in the work of Aquinas, Taparelli, Mill and Maitland, before its articulation by Pius XI (1931).
\end{abstract}

Keywords: Subsidiarity, Political Philosophy, Aristotle, Catholic Social Teaching

The principle of subsidiarity—better put: of subsidiary responsibility—is (i) a development of the Aristotelean political science/theory, and (ii) drawing on but going well beyond Aristotle's critique of Plato's communism. But, properly understood, it (iii) entails a rejection of a key tenet of Aristotle's own political theory.

The principle has a sense and content that I tried to sum up in Natural Law and Natural Rights:

[T] he principle is one of justice. It affirms that the proper function of association is to help the participants in the association to help themselves or, more precisely, to constitute themselves through the individual initiatives of choosing commitments (including commitments to friendship and other forms of association) and of realizing these commitments through personal inventiveness and effort in projects (many of which will, of course, be co-operative in execution and even communal in purpose). And since in large organizations the process of decision-making is more remote from the initiative of most of those many members who will carry out the decision, the same

* Biolchini Family Professor of Law, University of Notre Dame; Professor of Law and Legal Philosophy Emeritus, University of Oxford. Email: john.finnis@law.ox.ac.uk. 
principle requires that larger associations should not assume functions which can be performed efficiently by smaller associations. ${ }^{1}$

So "subsidiarity" is shorthand for "the principle of subsidiarity," which in turn is shorthand for "the principle of subsidiary function/responsibility," shorthand for the principle that it is unjust for a higher ${ }^{2}$ authority to usurp the self-governing authority that lower authorities, acting in the service of their own members (groups and persons), rightly have over those members. This requirement of justice is not one of the exceptionless negative moral norms, picking out a kind of act that (a) ought always to be excluded from deliberation and choice, and (b) can be identified by reference to its object (specific intention) without reliance on other moral judgments. Rather, this is a principle of justice that, in its application to intentions and circumstances, takes its place within a matrix of other moral judgments ${ }^{3}$ about what is required to do justice to those whose wellbeing will be affected by action or inaction in those circumstances. Its force, therefore, is substantial but presumptive and defeasible. Even in relation to non-instrumental groups such as families and religious associations, the principle excludes neither regulation by state law nor the assumption of strong internal managerial functions for the prevention of concrete injustices to vulnerable members or to third parties. It does exclude a policy or aim of assuming such control and managerial direction as the "default" (presumption). ${ }^{4}$

(i) We can see the rationale of the principle's proto-emergence as a development of Aristotelean political theory, in the prologue to Aquinas's commentary on Aristotle's Nicomachean Ethics. Using Latin synonyms for subsidium (help, assistance), Aquinas says in para. 4:

Because one (each of us) is by nature a social animal needing for one's life many things one cannot get for oneself if alone, one is naturally a part of a group that furnishes one help [auxilium] to live well. One needs this help in two respects. First, to have the

${ }^{1}$ John Finnis, Natural Law and Natural Rights [NLNR], 2d ed. (Oxford: Oxford University Press, 2011; $1^{\text {st }}$ ed. 1980), 146. The endnote to this, on p. 159, quotes the principle's articulation in Pius XI, encyclical Quadragesimo Anno (1931), para. 79:

\footnotetext{
just as it is wrong to withdraw from the individual and commit to a group what private initiative and effort can accomplish, so too it is a wrong ... for a larger and higher association to arrogate to itself functions which can be performed efficiently by smaller and lower associations. This is a fixed, unchanged and most weighty principle of moral philosophy.... Of its very nature the true aim of all social activity should be to help [subsidium afferre] members of a social body, and never to destroy or absorb them.
}

I added: "Later pronouncements of the Roman Catholic authorities have applied the principle to relationships of production in the economy $(1961,1967)$, to world political order (1963) and world economic order (1965), to the relationships between families, schools, and the state (1965), to the ecclesiastical community (1969), and to politics at all levels (1971)." See also n. 27 below.

2 In this context, "higher" and "greater" are to be understood as in the service of - as means to the flourishing of- "lower" and "lesser," of which some are substantive (individual-persons) or associational (nuclear familial) ends in themselves, and others are [= can and should be] associations of a worth as means equal or greater to that of the associations higher/greater in coercive authority and responsibility.

3 Signaled in the foregoing statement of the principle by the word "usurp."

${ }^{4}$ See the debate between Leslie Green and me in Reason, Morality \& Law, ed. John Keown and Robert P. George (Oxford: Oxford University Press, 2013), 186-203, 510-18, esp. 514-5. 
necessaries without which no-one can subsist and get through the present life; and for this, one is helped (auxiliatur] by the domestic group of which one is a part. For one is indebted to one's parents for one's generation, nourishment and instruction. Likewise individuals, as family members, help [iuvant] one another to procure the necessities of life. From the group of which one is a part, one receives help In another way, towards a more complete sufficiency for life; namely, that one may not only live but live well, having everything sufficient for living; and in this way one is helped [auxiliatur] by the civic group of which one is a member, not only in regard to bodily needs - as, in the political community, there certainly are many crafts which a single household cannot provide-but also in regard to right conduct [moralia], inasmuch as public authority restrains with fear of punishment recalcitrant young people whom paternal admonition is not able to correct.

Such reasoning from needs is a primary key to Aristotelean method in the theory of human affairs, ${ }^{5}$ and is operative in the explanation of subsidiarity offered in Natural Law and Natural Rights:

What is the source of this principle? I touched on it when I discussed the 'experience machine'.. ${ }^{6}$ Human good requires not only that one receive and experience benefits or desirable states; it requires that one do certain things, that one should act, with integrity and authenticity; if one can obtain the desirable objects and experiences through one's own action, so much the better. Only in action (in the broad sense that includes the investigation and contemplation of truth) does one fully participate in human goods. One cannot-no one can-spend all one's time, in all one's associations, leading and taking initiatives; but anyone who is never more than a cog in big wheels turned by others is denied participation in an important aspect of human well-being. ${ }^{7}$

All this is at least implicit in Aristotle's own reflections on human nature, reflections most fully developed in his practical-theoretical treatise on what is needed for human flourishing, the Nicomachean Ethics. Indeed, the taproot of the principle of subsidiarity can be said ${ }^{8}$ to be implicit in Aristotle's distinction between practical reasonableness (phronesis) and technical ability (techne) (in other words, between "doing something" and "making something"): "making aims at an end distinct from the act of making, whereas in doing the end cannot be other than the act itself: doing well is in itself the end." "More vivid perhaps is Cicero: "[Practical] wisdom is not like seamanship or medicine, but like the arts of acting and of dancing-for its end, being the actual exercise of the art, is contained within the art and is not something extraneous to it." ${ }^{10}$ And of course, living a life (and shaping a character) by choice and self-direction matters more than play-acting or the dance.

${ }^{5}$ See a working out of this in John Finnis, "The Nature of Law" in Cambridge Companion to the Philosophy of Law, ed. John Tasioulas (Cambridge, Cambridge University Press, forthcoming 2017).

6 See NLNR, 95-6.

7 NLNR, 147.

8 As NLNR, 197 says.

9 Nicomachean Ethics 6.4: 1140b3-6; see also 2.4: 1105a32. On this intransitivity of morally significant (good or bad) choice, see Finnis, Fundamental of Ethics (Oxford and Georgetown: Oxford University Press and Georgetown University Press, 1983), 138-42, 152-3.

${ }_{10}$ De Finibus 2.7.24. 
(ii) A more immediate context of the principle's implicit emergence is, perhaps, Aristotle's critique of Plato's proposal in the Republic that it would be good to have a sharing of wives and children, and of goods and possessions:

So Aristotle had to begin his Politics with some reminders. Friendship is nothing if it is not willing the good of one's friend, committing oneself to helping in one's friend's self-constituting participation in any or all of the basic aspects of human flourishing. In the first place, then, there will be no friendship if there is no commitment, and to commit oneself is, in this finite life, to turn aside from an inexhaustible multitude of alternative commitments that one might have made. In the second place, one can give nothing to a friend unless one has something of one's own to give... . Only a family or quasi-family can build up over time that common stock ... which each member holds at the others' disposal, and which ... constitutes an incomparably fine thing for a friend to give or receive... . Plato's proposal, made in the name of friendship, is tantamount to a drastic dilution, 'watering-down', ${ }^{11}$ of friendship — a radical emaciation of a basic aspect of human well-being... .

Still, as Aristotle also points out, if the family is thus to contribute to this growth of its members in freedom, friendship, and all-round good, it must be liberated from the requirement of unremitting toil by all its members for material necessities. Things will be better for everyone if there is a division of labour between families, specialization, technology, joint or co-operative enterprises in production and marketing, a market and a medium of exchange, in short, an economy that is more than domestic. And the same goes for the other goods participated in by the family. The resources not only of material goods and of technology, but also of language, of knowledge, of aesthetic experience, of interpersonal concern and religious aspiration, are all more ample than any family can mediate to its members by itself. Hence, the members of a family will flourish more fully if, without dissolving their family, they enter into a whole network of associations with their neighbours. Aristotle speaks of this level of associations as essentially the community of neighbourhood. But neighbourhood need not be merely geographical. ${ }^{12}$

11 Politics 2.1: $1262 \mathrm{bl} 7$.

12 NLNR, 144-6. Russell Hittinger helpfully summarises the relevant points made in Aquinas's commentary on Aristotle:

(1) that although polity has a divine-like dignity, it is not socially homogeneous [includit omnes alia communitates, ad lib. 11.1 n. 3]; (2) that the diversity contained in polity cannot be reduced to quantity [quia differentia quae est secundum magis et minus non diversificat speciem, ad lib. $1.1 .1 \mathrm{n}$. 6]; (3) that the social components are themselves complex, for even the household consists not merely of distinct functions but distinct modes of union, e.g. spouses, children, servants [nos. 9, 11, 17, 19, 24]; (4) that it is necessary to distinguish between a common good (bonum commune) and goods commonly pooled (bona communia) [lib. 2.1 n. 10.]; (5) that a progressive series of unifications within the body politic would produce another individual rather than a society, and in so doing polity would be destroyed [lib. 2.1 n. 11.]; (6) in conclusion of which, we can understand that a polity should not have maximum unity [unde patet falsum esse quod Socrates dixit optimum esse in civitate quod sit maxime una, lib $2.11 \mathrm{n}$. 16].

"The Process of 'Creative Destruction' and Subsidiarity: A Response to Professors Archer and Donati," in Crisis in a Global Economy. Re-planning the Journey (Pontifical Academy of Social Sciences, Acta 16, 2011), ed. José T. Raga and Mary Ann Glendon (Vatican City: Pontifical Academy of the Social Sciences, 2011), 165 (available at: www.pass.va/content/dam/scienzesociali/ pdf/acta16/acta16-hittinger.pdf). 
We get closer to the core of subsidiarity when we reflect that, just as the dissolution of family and property would water down human friendship, so the complete absorption by the family of its members would radically emaciate their personal freedom and authenticity, which also are basic aspects of human fullbeing. The justification for the family, for its contractual or quasi-contractual permanence and exclusiveness, for its possessiveness and its possessions, presupposes that each member of the family is to be enabled by family life and support to grow in self-possession (of which self-giving in friendship is one basic aspect).

So subsidiarity is a development of Aristotelean practical reasonableness and of its theory.

(iii) Yet the subsidiarity principle also rejects, or at least disambiguates, radically, a cardinal principle of Aristotle's Politics, formulated near the beginning of the work in these terms:

Because it is the completion of associations existing by nature, every polis exists by nature, having itself the same quality as the earlier associations from which it grew. It is the end or consummation to which those associations move, and the "nature" of things consists in their end or consummation... Again, the end or final cause is the best. Now self-sufficiency [autarkeia] [which it is the object of the state to bring about] is the end, and so the best. ${ }^{13}$

What the principle of subsidiarity both emerges from and points to is a conception of the political community's common good as a wellbeing in which is included-and not merely as a means to any such end as the autarkeia of the whole-the flourishing of individuals and families and their appropriate associations.

Common good is fundamentally the good of individuals (an aspect of whose good is friendship lived out in community, that is, in groups or communities each of which has its common good). Common good, which is the object of all justice and which all reasonable life in community must respect and favor, is not to be confused with the common stock (bona communia), or the common enterprises, that are among the means of realizing common good. Common enterprises and the exploitation and creation of a common stock of assets are alike for common good because they are for the benefit of the individual members of the community to which they pertain: talk about benefiting "the community" is no more than a shorthand (not without dangers) for benefiting the members of that community. The fundamental task of practical reasonableness is self-constitution or self-possession; inner integrity of character and outer authenticity of action are aspects of the basic good of practical reasonableness, as are freedom from the automatism of habit and from subjection to unintegrated impulses and compulsions; even friendship, in its ordinary sense, and the intense community of family require and entail a certain specialization and limitation of one's attentions; in short, no common enterprise can itself bring about the all-round flourishing of any individual. An attempt, for the sake of the common good, to absorb the individual altogether 
into common enterprises would thus be disastrous for the common good, however much the common enterprises might prosper. ${ }^{14}$

Against Aristotle's ambiguous "self-sufficiency" of the political community, we should therefore hold that common enterprises are to be regarded, and practically conducted, not as ends in themselves but as means of assistance, as ways of helping individuals to "help themselves" or, more precisely, to constitute themselves. And in all those fields of activity, including economic activity, where individuals, or families, or other relatively small groups, can help themselves by their own private efforts and initiatives without thereby injuring (either by act or omission) the common good, they are entitled in justice to be allowed to do so, and it is unjust to require them to sacrifice their private initiative by demanding that they participate instead in a public enterprise. It remains unjust even if the material dividend they receive from the public enterprise is as great as or even somewhat greater than the material product of their own private efforts would have been. The principle of subsidiarity is a principle of justice. ${ }^{15}$

To mark his advance over Aristotle's political theory, Aquinas deploys the concept of public good, which I expound in a whole chapter of Aquinas: Moral, Political, and Legal Theory (1998). A summary paragraph:

Public good is a part or aspect of the all-inclusive common good. It is the part which provides an indispensable context and support for those parts or aspects of the common good which are private (especially individual and familial good). It thus supplements, subserves, and supervises those private aspects, but without superseding them, and without taking overall charge of, or responsibility for them. "Neither in one's whole being nor in one's belongings is one subordinate to the political community." 16 And here we may add Aquinas's partial anticipation of the principle of subsidiarity: ${ }^{17}$ "it is contrary to the proper character of the state's government (contra rationem gubernationis [civitatis]) to impede people from acting according to their responsibilities (offcia) except of course in emergencies." 18

\section{II}

Essential background to modern articulations of the principle of subsidiarity is its repudiation, in effect, by the French revolutionary doctrine which F.W. Maitland emphasized, as the antithesis of his own, in his Sidgwick Lecture in 1903, "Legal

14 NLNR, 168.

15 NLNR, 169.

16 Summa Theologiae I-II q. 21 a. 4 ad 3: homo non ordinatur ad communitatem politicam secundum se totum, et secundum omnia; "and so not all one's acts are meritorious or culpable by virtue of their relationship to that community."

17 Namely, that it is unjust for more extensive associations to assume functions which can be performed efficiently by individuals or by less extensive associations, since the proper function of instrumental associations is to help their members help themselves: see $N L N R, 146,159$.

18 Summa contra Gentiles III c. 71 n. 4 [2470]. What are these responsibilities? Marriage is one natural responsibility (officium naturae humanae) with which human law is rightly concerned (IV Sent. d. 27 q. 1 a. 3 sol. 1 ad 1; d. 31 q. 1 a. 2 c $\&$ a. 3 sed contra 2; d. 39 q. 1 a. 2 ad 3) and a community responsibility (in officium communitatis) (d. 34 q. 1 a. 1 ad 4). 
Personality and Moral Personality." Here is his translation of the declaration of the revolutionary assembly on 18 August 1792: "A State that is truly free ought not to suffer within its bosom any corporation, not even such as, being dedicated to public instruction, have merited well of the country." Maitland adds: "It is always best to begin with France, and there, I take it, we may see the pulverising, macadamising tendency in all its glory, working from century to century, reducing to impotence, and then to nullity, all that intervenes between Man and the State." 19 Maitland saw Roman Law as a potent cause of this tendency long before the doctrinal excesses of the Revolution, and traced the vitality and reality of unincorporated, voluntary associations in English civic life to English law's evasion of the Roman law idea of the corporation as depending for its existence on the sovereign's grant - the primary vehicle of this evasion being the trust, eluding the Roman law's insistence that what is not Property must be Obligation (essentially, contract).

English political thought about these matters, in the era into which Maitland was born in 1850, can be seen to advantage in Mill's Principles of Political Economy (1848):

The true reasons in favour of leaving to voluntary associations all such things as they are competent to perform would exist in equal strength if it were certain that the work itself would be as well or better done by public officers. These reasons have been already pointed out: the mischief of overloading the chief functionaries of government with demands on their attention, and diverting them from duties which they alone can discharge, to objects which can be sufficiently well attained without them; the danger of unnecessarily swelling the direct power and indirect influence of government, and multiplying occasions of collision between its agents and private citizens; and the inexpediency of concentrating in a dominant bureaucracy all the skill and experience in the management of large interests, and all the power of organized action, existing in the community; $a$ practice which keeps the citizens in a relation to the government like that of children to their guardians, and is a main cause of the inferior capacity for political life which has hitherto characterized the over-governed countries of the Continent, whether with or without the forms of representative government.

But although, for these reasons, most things which are likely to be even tolerably done by voluntary associations should, generally speaking, be left to them; it does not follow that the manner in which those associations perform their work should be entirely uncontrolled by the government. ${ }^{20}$

And here Mill turns to consider quasi-monopolies such as water or gas suppliers, and railways, regulation of maximum hours of labor, and so forth.

Earlier in the same decade, Luigi Taparelli d'Azeglio, S.J. published his Saggio Teoretico di Dritto Naturale [Theoretical Essay on Natural Law/Right] (1840-43). At the heart of this eclectic work (which Pius IX was recommending to Catholic

19 F.W. Maitland, Collected Papers (Cambridge: Cambridge University Press, 1911), 3: 303. For an illuminating discussion of Maitland's political theory (as illustrated in this 1903 Lecture), and of its high, exceptional worth, see Alan Macfarlane, "F. W. Maitland and the Riddle of the Modern World: Maitland Memorial Lecture 2000," http://www.alanmacfarlane.com/FILES/down_fwm.htm

20 John Stuart Mill, Principles of Political Economy with Some of Their Applications to Social Philosophy ([1848][1885] bk 5, ch. 11, sec. 11 (emphases added)). 
students as late as 1929) 21 is an ambitious, metaphysical sounding but really normative ethical-social theory which will have contributed to the thought of the two philosophers Matteo Liberatore, S.J. and Tommaso Zigliara, O.P.each an accomplished philosophical proponent of Aquinas-who drafted Leo XIII's encyclical, Rerum Novarum (May 1891). Here subsidiarity, without being named, is expounded with wide generality in the treatment of liberty, family (property, parent and child) and state, and later of trade unions. Taparelli d'Azeglio speaks of (1) the assistance [sussidio soziale] needed by and afforded to everyone by associating with members who supply aid [concorso], directed by authority, in associations [consorzi] where the administrator knows the needs of the individual and applies the forces of the association to help [a sussidio]; ${ }^{22}$ (2) the duty of the Whole not to destroy the associations subordinated to it in a sistema ipotattico di associazione [a system of mutually subordinated associations in which the duty of the whole is to safeguard the existence and flourishing of the parts] ${ }^{23}$ (3) the persistence of associations even after the collapse of the Whole [the state]; ${ }^{24}$ (4) the validity of these principles whether the sistema ipottatico results from division or composition, and whether the subordinated associations [parts] have been created by nature, agreement or law. ${ }^{25}$ He takes his neologism ipotattico from the Greek hypo-taxis [under-placed], which approximates to the Latin word sub-sidium for the third, reserve line of troops in the order of battle or, more generally, the auxiliary force(s) - and thus by extension a word for support, aid, assistance, protection, etc. ${ }^{26}$

So Rerum Novarum says the state should respect the individual's antecedent right to marry, uphold the family's rights to own property, and treat the child below the age of reason as neither autonomous nor a ward of the state but as part of the family (paras. 12-14). And trade unions, like other private associations, have the same kind of right to be formed and exist under their own direction as the state does (paras. 48-52). In each case, the state's authority and responsibility to step in and exercise any kind of direction within the association is exceptional, and is predicated on some collapse or some abuse of right within the family or other association.

21 Pius XI encyclical Divini Illius Magistri (On Christian Education) (1929), para 50 (on civic education) n. 33 (calling the Saggio Teoretico "a work never sufficiently praised and recommended to university students (cfr. Our Discourse of Dec. 18, 1927)." Note that footnote 28 of this encyclical reads:

28. "The fundamental theory of liberty upon which all governments in this Union repose excludes any general power of the State to standardize its children by forcing them to accept instruction from public teachers only. The child is not the mere creature of the State; those who nurture him and direct his destiny have the right coupled with the high duty, to recognize, and prepare him for additional duties." U.S. Supreme Court Decision in the Oregon School Case, June 1, 1925 [Pierce v Society of Sisters 268 U.S. 510.]

22 Luigi Taparelli, Saggio Teoretico di Dritto Naturale Appoggiato sul Fatto, $2 \mathrm{~d}$ ed. (Livorno, 1851), no. 691 .

23 Ibid., nos. 694-7, 713-4.

24 Ibid., no. 699.

25 Ibid., nos. 696, 710:

26 "hypotaxis" as a grammatical term for the use of subordinate clauses seems to emerge after (and quite independently of) Taparelli. 
A century later, John Paul II's 1991 encyclical Centesimus Annus, citing Pius XI's Quadragesimo Anno (1931), states "the principle of subsidiarity" thus:

a community of a higher order should not interfere in the internal life of a community of a lower order, depriving the latter of its functions, but rather should support [sustentare] it in case of need, and help [adiuvare] to coordinate its activity with the activities of the rest of society, always with a view to the common good. ${ }^{27}$

The Treaty on European Union done at Maastricht in 1992 introduced an article on subsidiarity, which in its present form (Lisbon, 2009) states in art. 5:

5.3: Under the principle of subsidiarity, in areas which do not fall within its exclusive competence, the Union shall act only if and in so far as the objectives of the proposed action cannot be sufficiently achieved by the Member States, either at central level or at regional and local level, but can rather, by reason of the scale or effects of the proposed action, be better achieved at Union level.

Protocol 2 to the Treaty, on the application of the principles of subsidiarity and proportionality, has a single-clause explanatory recital: "Wishing to ensure that decisions are taken as closely as possible to the citizens of the Union ..." A typical academic exposition of all this will say something like: "The principle of subsidiarity means that the EU must not undertake or regulate what can be managed or regulated more efficiently at national or regional levels." 28

None of these EU concepts-better (or worse or insufficient) efficiency for achieving presupposed "objectives" of some "proposed action"; deciding on the action "close to the peoples" - is adequate to stating or understanding the principle. They remain within the framework of French revolutionary flattening out of social and political thought denounced by Maitland: the reduction of social realities and issues to "individual and state/Society."

27 Centesimus Annus, para. 48. One of the two documents of the Second Vatican Council that mention the principle calls it, twice, the principle of subsidiary responsibility (principium subsidiarii officii): Gravissimum Educationis (1965) 3 and 6. This is the phrase used in Quadragesimo Anno (1931), para. 80.

${ }^{28}$ Nicholas Moussis, Access to European Union Law, Economics, Policies, $21^{\text {st }}$ ed. (Rixensart, Belgium: Edit-Eur, 2015), 3.2. The principle was introduced into EU law by the Treaty of European Union done at Maastricht, 7 February 1992, and was not otherwise a general principle of European law cognizable by the court of the Union: Vereniging van Samenwerkende Prijsregelende Organisaties in de Bouwnijverheid v Commission of the European Communities, judgment of 21 February 1995 (T-29/92, Court of First Instance, ECJ). 